\title{
ARTICLE
}

\section{Silk Textiles from the Topkapi Palace Museum, Istanbul: An Analytical Study}

\author{
Recep Karadag* \\ Istanbul Aydin University, Faculty of Fine Arts, Fashion and Textile Design, Istanbul-Turkey, \\ Turkish Cultural Foundation (TCF), DATU-Cultural Heritage Preservation and Natural Dyes \\ Laboratory, Istanbul-Turkey.
}

Received: $4^{\text {th }}$ Feb. 2021;

Accepted: $14^{\text {th }}$ Sep. 2021

\begin{abstract}
Eight historical textile objects belonging to the $16^{\text {th }}-20^{\text {th }}$ centuries in the collection of the Topkapi Palace Museum in Istanbul were analyzed with the purpose of reaching improved conservation and restoration methods. The historical textiles underwent dyestuff analysis by High Performance Liquid Chromatography, morphological and elemental analysis by Scanning Electron Microscope with energy Dispersive X-ray Spectroscopy, CIEL*a*b color measurement as well as technical analysis by optical microscopy.
\end{abstract}

Keywords: Metal threads, Elemental analysis, Dyestuff analysis, Fiber characterization, Color measurement.

\section{Introduction}

Textile is one of the important aspects that represent the cultural heritage of any society. Textiles function as fabrics and garments, home textiles, bags for storage and transport, as well as architecture architectural elements (carpets, kilims,...etc.) and as bearers of religion garments and cultural heritage. Textiles define our persons, our environment and the activities in which we engage ${ }^{[1]}$. Dyeing began around 5000 B.C., but using natural dyes began only at the early periods of the Bronze Age ${ }^{[2,3]}$ : For blue color, indigo dye plants, for purple, Murex sp., in 1727 B.C. Kermes ilicis, and later, lac (Kerria lacca Kerr) insects were used. In the early years of red colors, madder and insect dyes were used. For yellow, Reseda luteola L., Corcus sativus L. and Curcuma long L. dye plants were used. After the $16^{\text {th }}$ century, an insect called Dactylopius cocus Costa from South America was used. Synthetic dyes started to be used after $1856^{[4]}$. In the Ottoman period, to dye silk, kermes, lac, Polish kermes, Ararat kermes and cochineal dyes were used for red, woad for blue and green, weld for yellow and green and gall oak and valona oak for black ${ }^{[4]}$. Natural dyeing techniques have been the same since ancient times.

The analysis of natural dyes in historical textiles is a helpful tool to describe the dyeing methods. It is also related to the area of textile conservation and preservation, because it permits one to rebuild the original views of historical artworks and to foresee the durability of their colors and their physical and chemical characteristics and enable finding the correct restoration and conservation procedures. If, for example, wet cleaning is to be carried out on the historical textile, it is important that a solvent system can be prepared in which the contaminated layer is soluble, but the dye underneath is not. It is also very important for the restoration work that the restoration material to be used has the same chemical and physical properties as the historical textile. Hence, the restoration material should be dyed according to the color density in the colored part of the historic patch which should be supported with fabric. The hue of this color can be determined by color measurement. 
However, the quantity of material that can be examined is very limited because of the high value of the textile objects and, accordingly, the insufficient material available for analysis. Analyzing samples should be taken from the textile objects carefully without damaging or, if not possible, with too minimal damage. In such conditions, micro-analysis or non-destructive analyzing methods are needed ${ }^{[5]}$. Thus, many analytical methods have been used. For instance, HPLC (high-performance liquid chromatography) and TLC (thin-layer chromatography) ${ }^{[6-17]}$, UV-visible spectrometry, gas chromatogramphy ${ }^{[18]}$, optical microscopy and $\mathrm{FTIR}^{[19-20]}$. The most powerful analytical techniques right now are HPLC-DAD ${ }^{[21-22]}$ and LC-MS, which permit the separation and detection of the too many coloring compounds that contribute to the color of the fiber or yarn. The chromatographic methods require, however, the extraction of the coloring compound from the yarns or fibers, hence few milligrams of fiber or yarn should be eliminated from the objects. Furthermore, dyestuffs can be affected by the extraction process $^{[23]}$. The quantity needed for the analysis are, nevertheless, too small (approximately 3 or $5 \mathrm{~mm}$ of yarn or thread) and can mostly be provided from damaged regions ${ }^{[24]}$.

Metal threads, solid metal and strips were used in weaving and embroidery. The most valuable metals used include gold, silver, copper, gold and silver alloys or mostly gilt ${ }^{[25-26]}$. Advanced analytical techniques have been used to characterize them. SEM-EDX (Scanning Electron Microscope with Energy Dispersive Xray Spectroscopy) is one of the most commonly used methods for the analysis of metal yarn samples in historic textiles, where the chemical structure of a very small sample can be determined and changes in the physical structure can be detected ${ }^{[2,20,25,27-28]}$.

The Topkapi Palace Museum in Istanbul contains almost four thousand textile art objects, a part of which has been investigated earlier ${ }^{\text {[21- }}$ ${ }^{22,29]}$. In this study, eight, not investigated before, historical textile objects from the $16^{\text {th }}$ to $20^{\text {th }}$ century were selected as they needed restoration due to both storage conditions and the destruction that occurred over time. The objects were subjected to HPLC, SEM-EDX, color analyses as well as to optical microscopic examination to determine the coloring compounds, elemental composition of the metal threads, weaving technique and the color value.

\section{Materials and Methods}

All the natural dye samples, dyestuff reference standards and chemicals were provided by DATU-Cultural Heritage Preservation and Natural Dyes Laboratory in Istanbul, Turkey. The solvents used for dyestuff analysis and sample preparation were HPLC grade. Methanol $(\mathrm{MeOH})$, acetonitrile $\left(\mathrm{CH}_{3} \mathrm{CN}\right)$, trifluoroacetic acid (TFA), dimethyl formamide (DMF) were purchased from Merck (Darmstadt, Germany). Dimethyl sulfoxide (DMSO) was obtained from Sigma Aldrich (Darmstadt, Germany). The dye standards were used as references: gallic acid from Merck, ellagic acid and genistein from Alfa Aesar, alizarin, carminic acid, indigo, luteolin, apigenin, fisetin from Sigma-Aldrich, purpurin from Fluka. Kermesic acid, flavokermesic acid and indirubin were provided by Prof. Mohammad S. Mubarak in the INCO CT 2005 015406 MEDCOLOUR-TECH project. The samples were taken from the Topkapi Palace Museum textile collection.

Eight textile objects were worked in the Topkapi Palace Museum (Table 1). A total of twenty-four samples were taken from the eight textile objects: Twenty yarn samples $(5-10 \mathrm{~mm})$ were used for coloring compound analysis and four metal thread samples $(5-10 \mathrm{~mm})$ were used for elemental composition analysis.

For dyestuff analysis, the historical textile samples (0.5-2.0 mg) as well as reference samples were hydrolyzed with $\mathrm{H}_{2} \mathrm{O}: \mathrm{MeOH}: 37 \%$ $\mathrm{HCl}(1: 1: 2 \mathrm{v} / \mathrm{v} / \mathrm{v} ; 400 \mu \mathrm{L})$ in conical glass tubes for precisely $8 \mathrm{~min}$ in a water bath at $100{ }^{\circ} \mathrm{C}$ to extract the organic dyestuffs. After rapid cooling under running cold water, the solution was evaporated just to dryness in a water bath at 50 $65{ }^{\circ} \mathrm{C}$ under a gentle stream of nitrogen. The dry residue was dissolved in a $200 \mu \mathrm{L}$ of a mixture of $\mathrm{MeOH}: \mathrm{H}_{2} \mathrm{O}(2: 1 \mathrm{v} / \mathrm{v})$ and was centrifuged at $4000 \mathrm{rpm}$ for $10 \mathrm{~min}$. For blue color samples, the residue was dissolved in $0.2 \mathrm{~mL}$ of $\mathrm{N}, \mathrm{N}-$ dimethyl-formamide as indigotin is not soluble in $\mathrm{MeOH}: \mathrm{H}_{2} \mathrm{O}(2: 1 \mathrm{v} / \mathrm{v})$. All mixtures were filtered using polypropylene syringe filters $(0.2$ $\mu \mathrm{m})$ followed by injection of $25 \mathrm{and} / \mathrm{or} 50 \mu \mathrm{L}$ of the supernatant into the HPLC apparatus (Agilent Technologies, Germany; computer hardware: Hewlett Packard, USA) which includes a G1329A ALS autosampler and a G1315A diode-array detector. Chromatograms were obtained by scanning the sample from 191 to $799 \mathrm{~nm}$ with a resolution of $2 \mathrm{~nm}$ and the chromatographic peaks were monitored at 255 , 
268, 276, 350, 491, 520, 580 and $620 \mathrm{~nm}$. A G1322A vacuum degasser and a G1316A thermostated column compartment confining a Nova-Pak C18 analytical column $(3.9 \times 150 \mathrm{~mm}$, $4 \mathrm{~mm}$, part number WAT 086344; Waters, USA) were used. Analytical and guard columns were maintained at $30{ }^{\circ} \mathrm{C}$. Chromatographic separation of the hydrolyzed samples was performed using a gradient elution program with two solvents: $\quad \mathrm{A}, \quad \mathrm{H}_{2} \mathrm{O}: 0.1 \%$ trifluoroacetic acid (TFA) and $\mathrm{B}, \mathrm{CH}_{3} \mathrm{CN}$ (acetonitrile):0.1\% TFA. The flow rate was $0.5 \mathrm{~mL} /$ minute. Further experimental details of the HPLC method can be found in earlier reports ${ }^{[21,26,29]}$. The data was evaluated with Agilent Chemstation.

Table 1. Description of analyzed textile art objects.

\begin{tabular}{cccc}
\hline Inventory number & Century & Product & Weaving technique \\
\hline $13 / 30$ & $17^{\text {th }}$ & cloak & Kemha* \\
$13 / 569$ & $16^{\text {th }}$ & shalwar & Seraser** \\
$13 / 1530$ & $16^{\text {th }}-17^{\text {th }}$ & caftan & Seraser** \\
$13 / 1846$ & unknown & women dress & Brocade \\
$13 / 303$ & $16^{\text {th }}-17^{\text {th }}$ & caftan & Kemha* \\
$13 / 673$ & $16^{\text {th }}$ & shalwar & Seraser** \\
$13 / 884$ & $16^{\text {th }}$ & brocade & Kemha* \\
$13 / 1024$ & $16^{\text {th }}-17^{\text {th }}$ & shawl fabric & Seraser** \\
\hline
\end{tabular}

* Kemha; a heavy, rich and stiff fabric preferred by the palace and wealthy people. Both the warp and the weft of Kemha were of silk and the top row of the fabric was strengthened and reinforced by either gold or silver gilding.

** Seraser; among all the fabrics woven of gold and silver threads, seraser is the most impressive and expensive faabric.

The elemental composition analysis of the fiber structure, solid metal and metal thread samples was performed using a TESCAN Vega3 SEM (TESCAN, Brno, Czech Republic), equipped with backscattered electron (BSE), secondary electron (SE) detectors and an energydispersive $\mathrm{x}$-ray detection system. It is a thermionic emission SEM system that comes with tungsten heated filament. The composition analysis at individual spots on the sample surface provides powerful line scan and spectral element mapping functions. Each sample was analyzed by attaching to a carbon band that did not affect the analysis result. Elemental analyses were carried out at an electron energy of 20 or $30 \mathrm{keV}$ and a beam current of $1 \mathrm{nA}$. Moreover, to identify the fiber type and get a good image, fiber samples were coated with gold/palladium $(60 / 40)$ and the images were obtained at $5 \mathrm{keV}$ energy.

For the technical examination of the objects, a polarized optical microscope, OLYMPUS SZ61 (SZ2-ILST, camera C18U), was used. Technical analysis, such as weft-warp density, yarn twist direction, weaving type was carried out by optical microscopy. The average number of warps (yarn) and wefts (yarn) are 120-125 per centimeter.

The scientific determination of colors on historical textiles is extremely important for restoration works. The method used for this is to measure the colors numerically with CIEL*a*b* spectrophotometer. The CIEL*a*b*system is a three-dimensional space: $\mathrm{L}^{*}$ is the brightness of the color $\left(L^{*}=0\right.$ : black, $L^{*}=100$ : white), $a^{*}$ is green-red axis $\left(a^{*}\right.$ negative: green, $a^{*}$ positive: red). $b^{*}$ is blue-yellow axis ( $b^{*}$ negative: blue, $\mathrm{b}^{*}$ positive: yellow ${ }^{[27,30]}$. Color measurement was performed using a Konica Minolta CM2300d device and Spectra Magic NX (6500 K, $10^{\circ}$ ) for software which calculates the color in the CIEL*a*b* space $^{[31]}$. The spot diameter of CIEL*a*b* spectrophotometer is $2.5 \mathrm{~cm}$.

\section{Results and Discussion}

Table 2 represents the determined color values in the CIEL*a*b* space. The result defines in which color tone the restoration material should be dyed. Except object inventory $13 / 1846$, the $\mathrm{L}^{*}, \mathrm{a}^{*}$ and $\mathrm{b}^{*}$ values of other objects (inventories number objects 13/30, $13 / 303,13 / 673,13 / 884,13 / 1530,13 / 1024$ and 13/569) were comparable. 
Table 2. Color values of historical textiles.

\begin{tabular}{lllll}
\hline Inventory number & Color & $\mathbf{L}^{*}$ & $\mathbf{a}^{*}$ & $\mathbf{b}^{*}$ \\
\hline \multirow{3}{*}{$13 / 30$} & red & 33.54 & 34.81 & 7.38 \\
& yellow (metal thread) & 58.31 & 10.25 & 49.39 \\
& yellow & 58.77 & 9.91 & 42.33 \\
\hline \multirow{2}{*}{$13 / 303$} & brown & 67.97 & 3.79 & 16.46 \\
\hline \multirow{2}{*}{$13 / 673$} & red & 37.68 & 35.03 & 5.77 \\
\hline \multirow{3}{*}{$13 / 884$} & yellow & 44.41 & 17.22 & 33.39 \\
& red (fringe) & 44.65 & 39.25 & 9.27 \\
\hline \multirow{3}{*}{$13 / 1530$} & black & 21.06 & 0.83 & 2.51 \\
& yellow & 44.41 & 17.22 & 33.39 \\
& yellow (yarn of metal thread) & 53.55 & 7.52 & 25.10 \\
\hline & black & 38.76 & 21.92 & 14.95 \\
& yellow & 56.09 & 5.39 & 26.62 \\
$13 / 1024$ & yellow (yarn of metal thread) & 57.04 & 11.78 & 51.26 \\
& red (ground-weft) & 37.68 & 35.03 & 5.77 \\
& green & 42.98 & -42.14 & 27.34 \\
& blue & 61.29 & -7.86 & 2.77 \\
\hline $13 / 569$ & pink (ground-warp) & 64.19 & 54.94 & 6.70 \\
\hline $13 / 1846$ & green & 60.24 & -0.92 & 47.47 \\
\hline & red & 38.95 & 43.11 & 6.14 \\
\hline
\end{tabular}

In the restoration and conservation of historical textiles, technical analysis by a nondestructive analysis method is very important. Thanks to technical analysis, yarn type, number of yarn twist, number of plies, twist direction and weft-warp density are determined. In addition, the type of yarn or fabric to be used in the restoration process is determined. For example, if the twist direction of the yarns in the historic textile is " $\mathrm{S}$ ", the twist direction of the restoration yarn to be used must also be "S". If the twist direction used is in an opposite direction, such as "Z", the desired restoration process will not be successful, as it will reflect the light differently. Therefore, in the restoration process, it is important to make sure that the yarn thicknesses, yarn counts and yarn types are the same as in the yarn twist direction. Figure 1 represents the image obtained by optical microscopy of the inventory number $13 / 1530$. On average, there are 120 silk warp threads and 120 silk weft threads per centimeter. Weft and warp threads are "Z" twist.

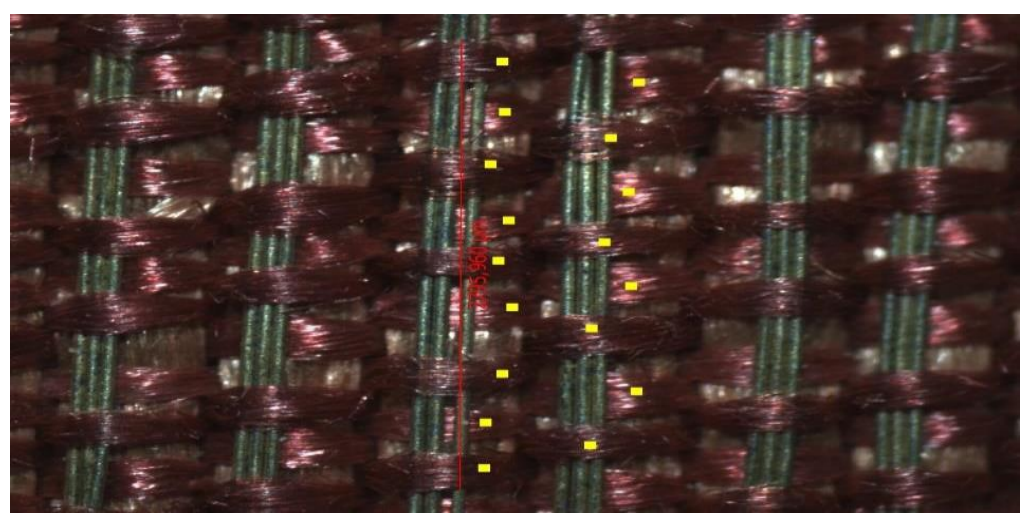

Figure 1. The optical microscopy images of the historical textile belonging to inventory number $13 / 1530, \times 30$ magnification. 
In the technical analysis of the historical textiles, especially in the $16^{\text {th }}$ century, silk brocade textiles were found to have an average warp density of 120-125 yarns/cm, while it was reported to be 96 yarns $/ \mathrm{cm}$ in the $17^{\text {th }}$ and $18^{\text {th }}$ centuries and less than 70 yarns $/ \mathrm{cm}$ in the $19^{\text {th }}$ century. Our result shows that the weaving quality is very good. However, in the historical textiles used in the last period of the Ottoman period, it was observed that the quality of weaving decreased as in the case of metal yarn samples. The type of yarns used by the palace dynasty is mostly silk. Twist direction of the metal threads was determined as " $\mathrm{S}$ " and twist direction of silk cores was determined as " $Z$ ".

Figure 2a represents an example of the obtained HPLC chromatograms and shows that of the red sample of inventory 13/1846 (chromatographic peaks were monitored at 255, 268, 276, 350, 491, 520, 580, and $620 \mathrm{~nm}$ ). Figure $2 \mathrm{~b}$ shows the electronic absorbance spectrum of fuchsine (retention time $27.13 \mathrm{~min}$ ) separated from the inventory 13/1846 (red line) and that of the standard (black line). According to the results of dyestuff analysis by HPLC, carminic acid, flavokermesic acid, laccain acids, luteolin, apigenin, genistein, fisetin, sulphuretin, ellagic acid, datiscetin, alizarin, indigotin and indrubin were detected (Table 3). Retention time and absorbance maxima of coloring compounds are given in Table 4. Probable biological dye sources were determined according to the detected dyestuffs in the objects and are given in Table 3. As it can be understood from here, insect dyes are the symbol of magnificence just like the shellfish used in dyeing during the Roman period. Red colors were obtained from dye insects and madder (Rubia tinctorum L.). Ordinary people had woven red-color garments dyed with madder, as insect dyes were too expensive than madder. Deep red colors used in dyeing silk were obtained from dye insects. Carminic acid and flavokermesic acid were detected in five objects $(13 / 30,13 / 303,13 / 673$, 13/1024 and 13/569). The coloring compounds of Dactylipous coccus and Porphyrophora hamalii are the same. At the times when the objects were produced, Dactylipous coccus had been widely used in the Ottoman Court dyeings $^{[2]}$. For this reason, the use of Dactylipous coccus in red is more likely than Porphyrophora hamalii.
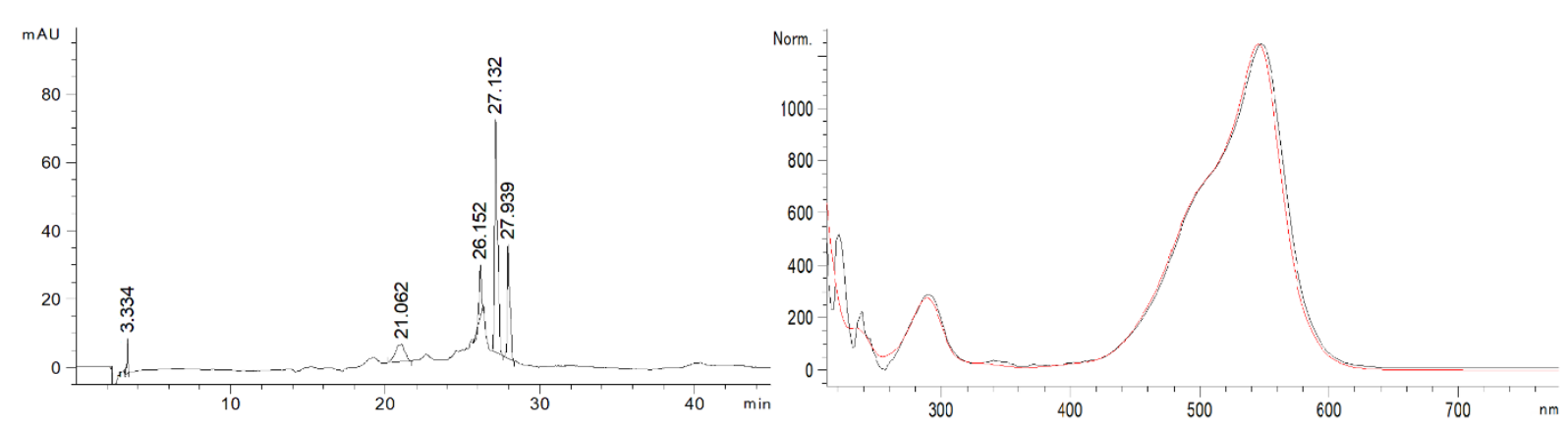

Figure 2. a) Chromatogram of the red sample (13/1846), b) spectrum of fuchsine (13/1846).

The results of the analysis of the yellow and green-color samples show that luteolin, apigenin, sulphuretin and genistein dyestuffs are the most abundant ones in these samples. The most used dye plants are expected to be weld, young fustic and dyer's greenwood. Indigotin dyestuff was detected in all the blue and green colors. This result shows that especially two plants can be used for green and blue colors. These plants are woad (Isatis tinctoria L.) and natural indigo (Indigofera tinctoria L.). However, considering that only woad is grown in Anatolia and Europe, it is highly possible that the samples in this color are dyed with woad. Also, it was determined that insect and indigo dyes were used together to produce purple colors. Fuchsine synthetic dye was found in the red sample in the inventory number 13/1846 object.

Thanks to SEM-EDX, fiber structures in the historical textile can be determined and the composition of metal components can be explored. The amount of damage in the yarn and metal samples due to time and environmental conditions can be determined by this method. In particular, it can be determined whether the yarns from the metal thread or solid metal in silk brocade fabrics damage historical textiles. Our studies showed that historical textiles containing gold in the metal parts are less affected by environmental factors than other textiles. If, 
however, the metal thread or solid metal contains an element such as copper, it is found to cause more damage to the historical textile ${ }^{[32-39]}$. This is because copper compounds are basic. Protein fibers undergo larger damage than cellulosic fibers in basic media. In addition, sulfur dioxide, hydrogen chloride, carbon

Table 3. Identified dyestuffs in the historical textiles selected.

\begin{tabular}{|c|c|c|c|}
\hline $\begin{array}{c}\text { Inventory } \\
\text { number }\end{array}$ & Color of Sample & Identified Dyestuff & Probable Dye Source \\
\hline \multirow{4}{*}{$13 / 30$} & black & ellagic acid, indigotin, indirubin & $\begin{array}{c}\text { Quercus infectoria } \text { Oliver or } \\
\text { Quercus ithaburansis Desicne } \\
+ \\
\text { Isatis tinctoria } \mathrm{L} . \text { or } \\
\text { Indigofera tinctoria } \mathrm{L} \text {. }\end{array}$ \\
\hline & black (tassel) & ellagic acid & $\begin{array}{l}\text { Quercus infectoria Oliver or } \\
\text { Quercus ithaburansis Desicne }\end{array}$ \\
\hline & red (fringe) & carminic acid & $\begin{array}{l}\text { Dactylopius coccus Costa or } \\
\text { Porphyrophora, hamalii Brandt }\end{array}$ \\
\hline & green & luteolin, apigenin, indigotin & $\begin{array}{c}\text { Reseda luteola } \mathrm{L} \text {. } \\
+ \\
\text { Isatis tinctoria } \mathrm{L} . \text { or } \\
\text { Indigofera tinctoria } \mathrm{L} .\end{array}$ \\
\hline \multirow[t]{2}{*}{$13 / 303$} & brown & ellagic acid, alizarin & $\begin{array}{c}\text { Quercus infectoria } \text { Oliver or } \\
\text { Quercus ithaburansis Desicne } \\
+ \\
\text { Rubia tinctorum } \mathrm{L} \text {. }\end{array}$ \\
\hline & red & carminic acid, flavokermesic acid & $\begin{array}{c}\text { Dactylopius coccus Costa or } \\
\text { Porphyrophora, hamalii Brandt }\end{array}$ \\
\hline \multirow[t]{2}{*}{$13 / 673$} & yellow & fisetin, sulphuretin ellagic, acid & Cotinus coggygria SCOP \\
\hline & red (fringe) & carminic acid, flavokermesic acid & $\begin{array}{l}\text { Dactylopius coccus Costa or } \\
\text { Porphyrophora, hamalii Brandt }\end{array}$ \\
\hline \multirow{3}{*}{$13 / 884$} & black & ellagic acid & $\begin{array}{l}\text { Quercus infectoria Oliver or } \\
\text { Quercus ithaburansis Desicne }\end{array}$ \\
\hline & yellow & luteolin, apigenin & Reseda luteola L. \\
\hline & $\begin{array}{l}\text { yellow (yarn of } \\
\text { metal thread) }\end{array}$ & sulphuretin & Cotinus coggygria SCOP \\
\hline \multirow{5}{*}{$13 / 1024$} & $\begin{array}{l}\text { red (ground- } \\
\text { weft) }\end{array}$ & $\begin{array}{l}\text { laccain acid } \mathrm{A}, \mathrm{B}, \mathrm{C}, \\
\text { carminic acid, flavokermesic acid }\end{array}$ & $\begin{array}{c}\text { Kerria lacca Kerr } \\
+ \\
\text { Dactylopius coccus Costa or } \\
\text { Porphyrophora, hamalii Brandt }\end{array}$ \\
\hline & $\begin{array}{l}\text { pink (ground- } \\
\text { warp) }\end{array}$ & $\begin{array}{c}\text { laccain acid } \mathrm{A}, \mathrm{B}, \mathrm{C} \text {, flavokermesic } \\
\text { acid }\end{array}$ & $\begin{array}{c}\text { Kerria lacca Kerr } \\
+ \\
\text { Kermes vermilio Planch }\end{array}$ \\
\hline & yellow & datiscetin & Datisca cannabine L. \\
\hline & green & datiscetin, indigotin & $\begin{array}{c}\text { Datisca cannabine L. or } \\
\text { Porphyrophora, hamalii Brandt } \\
+ \\
\text { Isatis tinctoria } \mathrm{L} . \mathrm{or} \\
\text { Indigofera tinctoria } \mathrm{L} \text {. }\end{array}$ \\
\hline & blue & indigotin & $\begin{array}{l}\text { Isatis tinctoria L.or } \\
\text { Indigofera tinctoria } \mathrm{L} .\end{array}$ \\
\hline \multirow[b]{2}{*}{$13 / 1530$} & yellow (lining) & luteolin, genistein & Genista tinctoria L. \\
\hline & green (tassel) & $\begin{array}{l}\text { luteolin, apigenin, indigotin, } \\
\text { indirubin }\end{array}$ & $\begin{array}{c}\text { Reseda luteola } \mathrm{L} . \\
+ \\
\text { Isatis tinctoria } \mathrm{L} . \mathrm{or} \\
\text { Indigofera tinctoria } \mathrm{L} \text {. }\end{array}$ \\
\hline $13 / 569$ & red & carminic acid & $\begin{array}{c}\text { Dactylopius coccus Costa or } \\
\text { Porphyrophora, hamalii Brandt }\end{array}$ \\
\hline $13 / 1846$ & red & fuchsine & Synthetic \\
\hline
\end{tabular}


Table 4. Chromatographic and spectral characteristics of the coloring compounds.

\begin{tabular}{ccc}
\hline Coloring compound & Retention time (min) & Absorbance maxima (nm) \\
\hline carminic acid & 16.11 & $223,274,310,348,476,495,532$ \\
flavokermesic acid & 25.90 & $220,283,343,431$ \\
ellagic acid & 17.47 & $251,301,367$ \\
luteolin & 23,82 & $253,267,289,347$ \\
apigenin & 26.52 & $265,293,337$ \\
fisetin & 19.47 & $253,305,320,354$ \\
genistain & 24.89 & 258,330 \\
sulphuretin & 22,92 & 257,399 \\
laccain acids & $15.31 ; 18.93 ; 22.30$ & $466,495,532$ \\
indigotin & 29.61 & $243,285,331,609$ \\
indirubin & 30.55 & $240,289,362,541$ \\
alizarin & 28,23 & $249,279,331,433$ \\
datiscetin & 25.20 & $257,305,347$ \\
fuchsine & 27.13 & 580 \\
\hline
\end{tabular}

dioxide and moisture are known to cause damage to historical textiles. Therefore, knowing the metal structure, especially in historical textile containing metal yarns, is extremely important for restoration and conservation. Silver and gold were detected as main elements in the analyses of the metal thread and solid metal samples, especially in the $16^{\text {th }}$ and $17^{\text {th }}$ centuries of the Ottoman period where high percentages of silver and gold were found ${ }^{[25]}$. However, the percentage of silver and gold has dropped in later periods with the pause and decline of the Ottoman Period. Thus, copper was found in yellow metal threads thought to be gold. In this study, the results of elemental analysis of the metal samples in investigated historical textiles are shown in Table 5 together with the SEM images shown in Figure 3. The metallic parts of the 13/1846 inventory number object contain high percentages of $\mathrm{Cu}(76.42 \%)$, suggesting that it belongs to the late Ottoman period. According to the dyestuff and metal thread analyses, 13/1846 inventory number object can be dated to the late $19^{\text {th }}$ century or early $20^{\text {th }}$ century. Because fuchsine dye was first synthesized in $1859^{[40]}$. For this reason, it is thought that this object may belong to after 1859 .

The analysis results (coloring compounds and metal threads) of the other objects suggest they belong, in terms of dyestuff and metal threads ${ }^{[2,21,25-27]}$, to the $16^{\text {th }}-18^{\text {th }}$ centuries. Chlorine and sulfur were identified in the 13/30 and 13/569 objects. Elements $\mathrm{S}$ and $\mathrm{Cl}$ are thought to come from the environmental conditions.

Table 5. Identified elements in metal samples.

\begin{tabular}{cccccccccc}
\hline & \multicolumn{8}{c}{ Identified elements and their percentages (\%) } \\
\cline { 2 - 10 } Inv. No. & $\mathbf{C}$ & $\mathbf{O}$ & $\mathbf{A l}$ & $\mathbf{S i}$ & $\mathbf{S}$ & $\mathbf{C l}$ & $\mathbf{C u}$ & $\mathbf{A g}$ & $\mathbf{A u}$ \\
\hline $13 / 30$ & 1.95 & 1.62 & 0.02 & - & 5.76 & 11.76 & 0.25 & 78.65 & - \\
$13 / 569$ & 7.28 & 4.13 & 0.38 & - & 1.18 & 3.53 & 1.32 & 82.18 & - \\
$13 / 1530$ & - & 4.46 & 0.62 & - & - & - & 0.11 & 85.90 & 8.92 \\
$13 / 1846$ & 14.18 & 6.58 & 0.18 & 0.09 & - & 0.02 & 76.42 & 2.54 & - \\
\hline
\end{tabular}




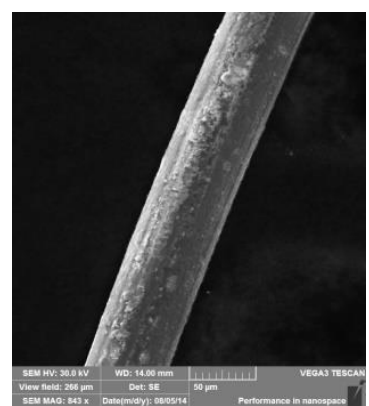

$13 / 569$

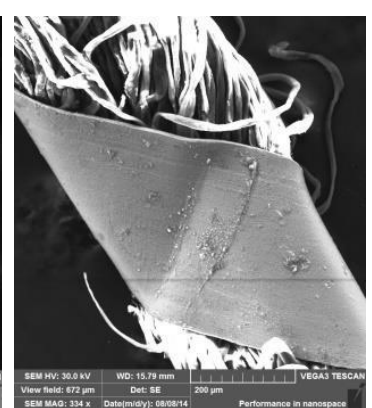

$13 / 1846$

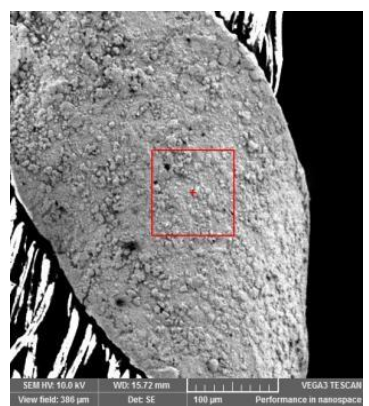

$13 / 30$

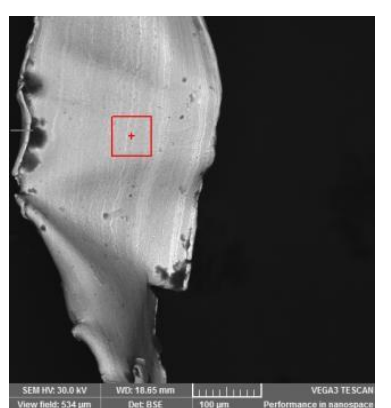

$13 / 1530$

Figure 3. SEM images of some metal samples.

\section{Conclusion}

In this work, eight historical textile objects were investigated with respect to their dyestuff and metal composition as a first and important step towards correct restoration and conservation as well as cleaning procedures. Carminic acid and flavokermesic acid were determined in the red colors of all objects except inventory number 13/1846. Red colors were most probably produced by dyeing with cochineal, black and brown colors by dyeing with gall oak or tannin dye plants, blue colors by dyeing with woad (Isatis tinctoria) or Indigifera tinctoria, yellow colors by dyeing with weld (Reseda luteola). Metal threads contain mainly silver excluding inventory number 13/1846. Identifying the weaving structure, color value, twist and spinning of yarns, detection of chemical compositions of metal threads, dyestuffs and dye sources of art objects is made possible by this work for accurate restoration, conservation and cleaning methods of objects.

\section{Acknowledgments}

The author would like to thank the Turkish Cultural Foundation (TCF) and its laboratory (DATU-Cultural Heritage Preservation and Natural Dyes Laboratory) for providing basic laboratory infrastructure and support: (www.turkishculturalfoundation.org; www.tcfdatu.org).

\section{References}

[1] Bier, C. ; Dusenbury, M.M., Textiles, In: Encyclopedia of Archeology, Elsevier, 2008, 2120-2125.

[2] Karadag, R. ; Torgan, E. ; Taskupru, T. ; Yildiz, Y., J. Liq. Chromatogr. Relat. Technol., 2015, 38, 591-599.

[3] Abdel-Kareem, O., Res. J. Text. Apparel, 2012, 16, 79-92.

[4] Shishlina, N. I.; Orfinskaya, O. V.; Golikov, V. P., Oxford J. Archaeol., 2003, 22, 331344.

[5] Kavkler, K. ; Demsar, A., Spectrochim. Acta, Part A, 2011, 78, 740-746.

[6] Surowiec, I. ; Orska-Gawry, J. ; Biesaga, M.; Trojanowicz, M. ; Hutta, M. ; Halko, R. ; Urbaniak Walczak, K., Anal. Lett., 2003, 36, 1211-1229.
[7] Clementini, C. ; Miliani, C. ; Romani, A. ; Favaro, G. ; Spectrochim. Acta, Part A, 2006, 64, 906-912.

[8] Degano, I. ; Ribechini, E. ; Modugno, F. ; Colombini, M. P. ; Appl. Spectrosc. Rev., 2009, 44, 363-410.

[9] Erkan, G. ; Sengul, K. ; Kaya, S. J., J. Saudi Chem. Soc., 2011, 18, 139-148.

[10] Bechtold, T. ; Turcanu, A. ; Ganglberger, E. ; Geissler, S., J. Cleaner Prod., 2003, 11, 499-509.

[11] Bechtold, T. ; Mahmud-Ali, A. ; Mussak, R., Dyes Pigm., 2007, 75, 287-293.

[12] Vankar, P. S. ; Shanker, R. ; Verma, A., J. Cleaner Prod., 2007, 15, 1441-1450.

[13] Vankar, P. S. ; Shanker, R. ; Mahanta, D. ; Tiwari, S. C., Dyes Pigm., 2008, 76, 207212. 
[14] Das, D. ; Maulik, S. R. ; Bhattacharya, S. C., Ind. J. Fiber Text. Res., 2008, 33, 163170.

[15] Karadag, R.; Yurdun, T.; Dolen, E., Asian J. Chem., 2010, 22, 7043-7056.

[16] Shibayama, N.; Wypyski, M.; Mangilli, G. E., Heritage Sci., 2015, 3, 1-20.

[17] Zarkogianni, M.; Mikropoulou, M.; Varella, E.; Tsatsaroni, E., Color. Technol., 2011, 127, 18-27.

[18] Surowiec, I.; Nowik, W.; Trojanowicz, M., Microchim. Acta, 2008, 162, 393-404.

[19] Papliaka, Z. E.; Konstanta, A.; Karapanagiotis, I.; Karadag, R.; Akyol, A. A.; Mantzouris, D.; Tsiamyrtzis, P., Archaeol. Anthropol. Sci., 2017, 9, 197208.

[20] Karadag, R.; Torgan, E.; Intern. J. Conserv. Sci., 2016, 7, 357-366.

[21] Yurdun, T.; Karadag, R.; Dolen, E.; Mubarak, S. M., Rev. Anal. Chem., 2011, 30, 153-164.

[22] Karapanagiotis, I.; Karadag, R.; Mediter. Archaeol. Archaeom., 2015, 15, 177-189.

[23] Gulmini, M.; Idone, A.; Diana, E.; Gastaldi, D.; Vaudan, D.; Aceto, M., Dyes Pigm., 2013, 98, 136-145.

[24] Karadag, R. ; Dolen E., Turk. J. Chem., 1997, 21, 126-133.

[25] Oraltay, R. G.; Karadag, R., Stud. Conserv., 2020, 65, 59-64.

[26] Kahraman, N.; Karadag, R.; Anal. Lett., 2017, 50, 1553-1567.

[27] Karadag, R.; Torgan, E., Text. Soc. America, 2012, 13, 1-13.

[28] Rezic, I. ; Curkovic, L. ; Ujevic, M., Talanta, 2010, 82, 237-244.
[29] Karadag, R.; Yurdun, T.; Dolen, E.; Identification of Dyes in Some $17^{\text {th }}$-century Silk Skullcaps in the Topkapi Palace Museum Collection by Liquid Chromatography with Diode Array Detection, In: The Diversity of Dyes in History and Archaeology; Kirby, Jo, Ed.; Archetype Publications, London, 2017, 251-256.

[30] Krikken, J. B.; Zijp, J. R.; Huysmans, M. C., J. Dent., 2008, 36, 731-735.

[31] Torgan, E.; Ozer L. M.; Karadag, R., Color Technol., 2015, 131, 200-205.

[32] Wouters, J., Stud. Conserv., 1985, 30, 119128.

[33] Gutarowska, B.; Pietrzak, K.; Machnowski, W.; Milczarek, M. J., Text. Res. J., 2017, 87, 2388-2406.

[34] Amin, A. E., Sci. Culture, 2018, 4, 35-46.

[35] Brosseau, C. L.; Gambardella, A.; Casadio, F.; Grzywacz, C. G.; Wouters, J.; Van Duyne, R. P., Anal. Chem., 2009, 81, 30563062.

[36] Amin, E. A., Intern. J. Conserv. Sci., 2018 , 9, 3-24.

[37] Ahmed, H. E., Intern. J. Conserv. Sci., 2014, 5, 21-34.

[38] Baek, Y. M.; Kwon, Y. S.; Goto-Doshida, S.; Masako Saito, M., J. Conserv. Sci., 2012, 28, 119-129.

[39] Richard, S.; Blackburn, R. S., Color. Technol., 2017, 133, 449-462.

[40] Cooksey, C.; Dronsfield, A.; Biotech. Histochem., 2009, 84, 179-183. 